\title{
Student Perceptions of Various E-Learning Components
}

\author{
Nicole A. Buzzetto-More \\ University of Maryland Eastern Shore, Princess Anne, MD, USA
}

\author{
NaBuzzetto-More@umes.edu
}

\begin{abstract}
Learning that is facilitated by electronic technologies, otherwise known as e-Learning, can be either fully online, mixed mode (also known as hybrid), or web assisted; however, regardless of the delivery method, there are numerous tools and features at the disposal of students and instructors, and it is important for the e-learning community to examine both preferences and usage of these features. This paper presents the findings of a comprehensive study that examined the elearning perceptions and preferences of students enrolled at a historically black university. During this study a series of courses were specially designed to be intensive hybrid learning experiences. The Blackboard CE 6 Course Management System was adopted and paper-less learning experiences created. The results of the analysis indicate that students find course Websites to be helpful resources that enhance the understanding of course content, and that these Websites will continue to have an impact on higher education in the future. The examination of individual e-learning components indicated that students responded favorably to most available features. The strongest preference noted in this study was towards the online submission of assignments, with students overwhelmingly noting that they like having the ability to check their assignment grades online.
\end{abstract}

Keywords: e-learning, asynchronous instruction, web-based instruction, minority education, hybrid learning, online learning, assessment, online examinations

\section{Background}

In 2005, the regents of the University System of Maryland instituted a policy that all students enrolling in a Maryland State University beginning in the fall of 2007 take on average 12 of their credits through out-of-classroom experiences and other nontraditional means with the definition of out-of-classroom experiences including: e-learning, internships, student teaching, and a host of other activities. This initiative not only stimulated the growth of e-learning in the State of Maryland but also sent a message to the larger educational community that the Maryland system has recognized that some online learning is an enhancement to students' higher-education learning

Material published as part of this publication, either on-line or in print, is copyrighted by the Informing Science Institute. Permission to make digital or paper copy of part or all of these works for personal or classroom use is granted without fee provided that the copies are not made or distributed for profit or commercial advantage AND that copies 1) bear this notice in full and 2) give the full citation on the first page. It is permissible to abstract these works so long as credit is given. To copy in all other cases or to republish or to post on a server or to redistribute to lists requires specific permission and payment of a fee. Contact Publisher@InformingScience.org to request redistribution permission. experience even when those students are full-time on-campus residents (Lorenzetti, 2005).

Established in 1886, the University of Maryland Eastern Shore (UMES) is a historically black, land grant institution and a member of the University System of the State of Maryland. The student population is approximately 4000, represented by a make up that is $74 \%$ Afri- 
can-American, $15 \%$ white, and $11 \%$ international, primarily coming from the continent of Africa and/or from the Caribbean region. The freshmen retention rate is $64 \%$, and the graduation rate is $42.6 \%$.

The institution is located in a rural region of Maryland, has an open acceptance policy, and is one of the most affordable four-year institutions of higher education in the State. With the institution's inexpensive tuition and minimal enrollment criteria, the University attracts a large number of students from a lower socio-economic background than is found in colleges and universities across the State (Ukoha \& Buzzetto-More, 2007). The Department of Business Management and Accounting is one of the largest departments on campus and is currently undergoing accreditation with the American Association of Colleges and Schools of Business International (AACSBI). The Department has approximately 420 majors, offering programs that include Business Administration, Marketing, Finance, Accounting, and Business Education. It was chosen for this study because of its size and adequate socio-economic representation of the larger student body.

Online leaning at UMES is facilitated by the Center for Instructional Technology which was created in 2006. The Blackboard CE 6 system, formally known as WebCT version 6, is the course management system utilized, and to date the University offers copious numbers of web-enhanced courses, numerous hybrid courses, and approximately thirty distinct fully online courses.

Historically Black Colleges and Universities (HBCUs), while small in number, graduate the preponderance of African Americans who earn college degrees in America (Hubbard, 2006). While, they constitute only 3 percent of U.S. colleges and universities, they enroll 28 percent of all African American college students and graduate 40 percent of the Black Americans who earn doctorates or first professional degrees (Hubbard, 2006). Their students have reported high levels of engagement, (Fries-Britt \& Turner, 2002), satisfaction, and instances of good practices (Seifert, Drummand, \& Pascarella, 2006). At the same time, their student population is shown to have a high percentage of first generation, low income, and under prepared students (Ukoha and Buzzetto-More, 2007).

HBCUs have been shown to successfully promote the college success of African Americans by fostering an environment that encourages student engagement, retention, and success (Flowers, 2002; Laird, Bridges, Homes, Morelon, \& Williams, 2004; Outcalt \& Skewes-Cox, 2002). A number of studies have examined and compared various aspects of the undergraduate experience of African-Americans at HBCUs versus the experience of African Americans at majority institutions and found that HBCUs, despite frequently fewer resources, are better at supporting African American undergraduates, resulting in higher graduation rates and more positive learning outcomes for students (Bohr, Pascarella, Nora, \& Terenzini, 1995; DeSousa \& Kuh, 1996; Flowers, 2002; Flowers \& Pascarella, 1999; Watson \& Kuh, 1996).

The prevailing assumption has been that a digital divide exists in higher education between majority and minority serving institutions (Hurd, 2000). When it comes to distance education, Arnone (2002) found it to be less prevalent and a "hard sell" at HBCU's. Recently, Buzzetto-More and Sweat-Guy (2006) found that while HBCU students came to college less technologically prepared, the use of e-learning is slowly rising in popularity with student perceptions of online learning viewed positively.

\section{Literature Review}

According to Nycz and Cohen (2007) e-learning is important for building a technologically literate workforce as well as for meeting societies continuous need for rapid life long learning delivered in increasingly more convenient forms. 
Kandies and Stern (1999) have asserted that Web-enhanced learning improves instruction and course management and offers numerous pedagogical benefits for learners. They explain that students in Web-enabled learning environments become more active and self directed learners, who are exposed to enhanced learning materials.

Course Websites have proved to be an effective means of delivering learning materials, with students responding positively to the quality resources they make available. Wernet, Olliges, and Delicath (2000), who surveyed students who used WebCT in a social work course, found that all of the respondents considered the online course materials beneficial to their overall learning experience.

Sanders and Morrison-Shetlar (2002) examined student attitudes with regard to the Web-enabled learning component in a general biology course for undergraduate non-majors. Their results showed a positive effect on student learning, problem-solving skills, and critical thinking skills, with females responding more positively than males.

Derouza and Fleming (2003) compared undergraduates who completed quizzes online with students who took traditional paper-based quizzes and found that the marks revealed that students who took the quizzes online significantly outperformed students who took the pencil-and-paper quizzes.

According to Connolly and Stansfield (2007) e-learning has gone through three distinct generations. The first generation, they explain, took place from 1994-1999 and was marked by a passive use of the Internet where traditional materials were simply repurposed to an online format. The second generation took place from 2000-2003 and was marked by the transition to higher bandwidths, rich streaming media, increased resources, and the move to create virtual learning environments that incorporated access to course materials, communications, and student services. The third generation is currently underway and is marked by the incorporation of greater collaboration, socialization, project based learning, and reflective practices, through such tools as eportfolios, wikis, blogs, social bookmarking and networking, and online simulations. Additionally, the third generation is increasingly being influenced by advances in mobile computing.

Learning that is facilitated by electronic technologies can be either fully online, mixed mode (also known as hybrid), or web assisted; however, regardless of the delivery method, the usage of learning technologies can transform the concept of teaching and learning by redefining the role of the teacher and transforming the meaning and content of the learning procedure (Anastasiades \& Retalis, 2001) where learning moves from a Tayloristic or behavioristic linear model that treats learners as products on an assembly line, to a more constructivist approach fostered by web-based instruction where learning is a more authentic self directed experience (Anastasiades \& Retalis, 2001; Buzzetto-More \& Sweat-Guy, 2006; Connolly \& Stansfield, 2007; DeVillers, 2007; Koohang \& Harmon, 2005; Lewis et al., 2005).

DeVillers (2007) introduced a model for the development of constructivist e-learning environments known as the Hexagonal-C Model. The framework for this model was built on six pillars with technology being subservient to the 'learning'. The six pillars of the Hexa-C Model are: 1) cognitive learning, fostered through the understanding of human comprehension, knowledge acquisition, and problem solving; 2) customization, otherwise known as the movement to individualize learning experiences to best meet the needs of learners; 3) constructivism, stimulated when interpretation, active learning, and anchored instruction are encouraged; 4) collaborative learning involving joint work, peer evaluation, intellectual camaraderie, social negotiation, and accountability; 5) creativity, fostered when creative and innovative strategies are employed; and 6) components which refers to an understanding of the learning outcomes and how different conditions best promote the building of different skills, dispositions, and/or knowledge bases. 
Educause Center for Applied Research conducted a longitudinal study (Caruso \& Kvavik, 2005; Caruso \& Salaway, 2007; Salaway, Katz, \& Caruso, 2006) that examined student uses, perceptions, and preferences with respect to technology. The most recent version of the study published in the fall of 2007 (Caruso \& Salaway) was based on a web based survey, focus group series, qualitative analysis of student comments, and longitudinal comparisons. According to the findings, students reported a mean average of 18 hours a week of online activity with email, online social networking, instant messaging, and document writing for course work being the most prevalent activities. Over $90 \%$ of the respondents reported having high-speed internet access with most students reporting that they are skilled at conducting online library research. While most students said they want to see technology incorporated in their courses, the majority reported that they like to see it used to a moderate degree $(59.3 \%)$ with $20.4 \%$ saying they favor extensive use, $15 \%$ preferring limited use, $2 \%$ preferring no usage, and $2.8 \%$ saying that they prefer the exclusive delivery of learning through IT. Student experiences with course management systems (CMS) increased from $72 \%$ in 2006 to $82 \%$ in 2007 with most (76.5\%) saying that the experience(s) were positive. Students were asked to rate the usefulness of a variety of popular CMS features ranked on a scale of 1-5 where 5 indicated extremely useful and 1 indicated not useful. The results are represented in Table 1.

Table 1: ECAR Survey Results (Caruso \& Salaway, 2007)

\begin{tabular}{|l|l|l|l|}
\hline Feature & N & Mean & Std. \\
\hline Keeping track of grades on assignments and tests online & 21,341 & 4.38 & .0925 \\
\hline $\begin{array}{l}\text { Online access to sample exams and quizzes for learning } \\
\text { purposes. }\end{array}$ & 19.924 & 4.17 & .0965 \\
\hline Online syllabus & 22,254 & 3.98 & 1.034 \\
\hline Turning in assignments online & 19,622 & 3.82 & 1.174 \\
\hline Online readings and links to other text based materials. & 21,949 & 3.81 & 1.056 \\
\hline Taking quizzes and exams online. & 17,848 & 3.66 & 1.250 \\
\hline $\begin{array}{l}\text { Getting assignments back online with instructor comments } \\
\text { and grades. }\end{array}$ & 16,314 & 3.74 & 1.252 \\
\hline Online sharing of materials among students. & 15,643 & 3.50 & 1.221 \\
\hline Online discussions. & 19,075 & 3.13 & 1.291 \\
\hline
\end{tabular}

Respondents also reported that technology helps in the conduction of course related research (70.5\% agreement) and in the facilitation of timely feedback from the instructor (73.3\% agreement). Students majoring in business, engineering, and technology exhibited the strongest preference for the usage of IT in education. Additionally, students who said that they prefer the usage of IT in their courses were more positive in their perceptions of the benefits of IT in the learning process and in their course engagement. Finally, the analysis of open ended survey questions showed that students feel that technology can facilitate organization and control of learning, communication with faculty and classmates, and access to materials and resources; however, respondents also expressed that poor use of technology can detract from the learning experience and that technology should support, not replace, face-to-face learning.

It is important to point out that while the ECAR study (Caruso \& Salaway, 2007) offers the educational community vital information; it is myopic in so far as that it has consistently neglected to 
involve the participation of minority serving institutions, preferring to focus attention on traditionally white institutions.

The results of the Caruso and Salaway (2007) ECAR study are consistent with the preponderance of research that is indicating that students are exhibiting strong preferences for the hybrid learning model. Furthermore, a number of instructional technology experts proclaim that the hybrid learning model offers the most superior method of delivering contemporary education (Buzzetto-More \& Sweat-Guy, 2006; Lorenzetti, 2005; Young, 2002). Hybrid courses blend face-to-face interaction with online learning, and although the hybrid format has received significantly less attention then its fully online cousin, I. Allen and Seaman (2003) found that the rate of growth of hybrid courses is exceeding that of fully online courses. Further, John R. Bourne, a professor of electrical and computer engineering at Franklin W. Olin College of Engineering and editor of the Journal of Asynchronous Learning Networks, was quoted in Young (2002) where he predicted that in the future $80-90 \%$ of all courses will become hybrid.

The benefits of hybrid learning are increasingly being realized as an escalating number of courses demonstrate the blended format to be the most popular mode of instruction (Buzzetto-More \& Sweat-Guy, 2006; Campos \& Harasim, 1999; Wu \& Hiltz, 2004; Young, 2002) with success rates equal to, or in many cases higher than, their fully online or face-to-face counterparts (Dziuban \& Moskal, 2001) noted by the highest levels of student satisfaction (Rivera, McAlister, \& Rice, 2002).

The hybrid learning model has been shown to be an effective and efficient way of expanding the learning process that supports in-depth delivery and analysis of knowledge (Young, 2002) while increasing student satisfaction (Buzzetto-More \& Sweat-Guy, 2006; Campos \& Harasim, 1999; Dziuban \& Moskal, 2001; Rivera, McAlister, \& Rice, 2002; Wu \& Hiltz, 2004).

In the years to come, hybrid learning is poised to cause a paradigm shift in higher education representing the future of learning in our digital age (I. Allen \& Seaman, 2003; Buzzetto-More \& Sweat-Guy, 2006; Lorenzetti, 2005; Young, 2002).

Are hybrid courses evaluated differently then traditional and fully online learning experiences? Carnevale (2000) found that regardless of the learning format, students took into consideration knowledgeable instructors, interaction with instructors, and additional features that create a sense of community when evaluating courses for merit. The importance of technological preparedness, willingness, and the overall mindsets of students has also been acknowledged by educators as playing a crucial role in both the hybrid and online learning equations. Further, Sanders and Morrison-Shetlar (2002) cited the importance of student attitudes toward technology as a significant determining factor in the educational benefits of online learning resources and experiences.

For many years, historically Black colleges and universities (HBCUs) have lagged behind majority institutions in the incorporation of e-learning into their curriculum (Buzzetto-More \& SweatGuy, 2006). Arnone (2002) found a reluctance towards distance education at HBCU's. This reluctance is often attributed to the very nature of HBCU's, which are known for small class sizes, high levels of student support, and highly targeted instruction (Buzzetto-More \& Sweat-Guy, 2007). This may also contribute to the strong preference report by HBCU students for hybrid instruction (Buzzetto-More \& Sweat-Guy, 2006).

HBCUs are minority serving institutions that have been proven to promote the college success of African American college students (Laird et al., 2004); however, despite their high success rates, Black students who attend HBCUs have been found to be from lower socio economic backgrounds, score lower on standardized tests, and be less prepared for college than Black students attending majority institutions (W. Allen, 1987; Buzzetto-More \& Sweat-Guy, 2007; Ukoha \& Buzzetto-More, 2007). With respect to technology, a number of prominent studies have found 
inequalities of computer and internet access across socio-economic and racial lines (Institute of Education Sciences, 2003; Morgan \& VanLegan, 2005; National Telecommunications and Information Administration, 2004). Further, the ways that students of different groups have been exposed to technology education and technology facilitated education has been shown to vary tremendously, with minority students from lower socio-economic backgrounds more likely to be exposed to drill and practice exercises, while white students from higher socio-economic backgrounds are more likely to benefit from technologies that help build, and require the use of, higher order thinking skills (Jackson, Ervin, Gardner, \& Schmitt, 2001).

Minorities have been found to be less likely to be technological literate; for example, when using the Internet African Americans and Hispanics have been shown to be less likely to search for news, and/or conduct informational searches (United States Department of Commerce, 2002). Sax, Ceja, and Teranishi (2001) conducted a nationwide survey of college freshmen and found that level of technological preparedness varied significantly by race, class, and academic background. They also found that racial differences with technology also persisted despite such key variables as parents' level of education and income and high-school type and concluded that the technological disparities are a hindrance to students' academic success. A more recent study conducted by Buzzetto-More and Sweat-Guy (2006) found marginal correlations between parents' level of education and technological ownership and readiness.

A study conducted in the fall of 2005 of 748 freshmen students at two HBCU's (Buzzetto-More \& Sweat-Guy, 2007) found that students attending HBCUs come to college with most of them owning computers, having internet access, having studied computers in high school, and considering themselves to be intermediate computer users. These numbers indicated growth from similar studies conducted previously at minority institutions but were still lower than what has been reported in the studies conducted at majority serving institutions. When prior educational exposure was examined, the majority of students indicated that they had used a computer to solve a problem as part of a class assignment, participated in group work that involved using computer software, and delivered a presentation using computer software. On the other hand, few students reported experiences with inquiry-oriented project-based learning and/or computer simulations. The findings also showed that students' perceptions and experiences with online learning were similar to the findings reported from studies conducted at majority institutions where students have reported that they want to see traditional learning supported by e-learning strategies; however, face-to-face instruction is preferred over fully online learning.

Another study conducted at an HBCU published in 2006 in the Journal of Information Technology Education (Buzzetto-More \& Sweat-Guy, 2006) found that hybrid learning increased students' course satisfaction with results that were in line with the findings of similar studies conducted at majority institutions. The study focused on the perceptions of 178 students enrolled in business communications courses delivered using the WebCT 4.2 course management system and found that students enjoyed the use of a course Website, felt that the course Website stimulated their desire to learn, and were content with both the quantity and quality of their online learning experiences. Although the respondents indicated an overwhelming willingness to enroll in future hybrid courses, a smaller majority said they would take a fully online course in the future. Table 2 illustrates these findings. 
Table 2: Student's Perceptions of the Use of WebCT (Buzzetto-More \& Sweat-Guy, 2006)

Response Category: $\mathrm{SA}=$ Strongly Agree, $\mathrm{A}=\mathrm{Agree}, \mathrm{N}=$ Neutral, $\mathrm{D}=$ Disagree, $\mathrm{SD}=$ Strongly Disagree

\begin{tabular}{|l|l|l|l|l|l|l|l|l|}
\hline & SA & $\mathbf{A}$ & $\mathbf{N}$ & $\mathbf{D}$ & SD & STD & Mean & $\mathbf{N}$ \\
\hline $\begin{array}{l}\text { I was satisfied with the } \\
\text { overall experience us- } \\
\text { ing WebCT }\end{array}$ & $42 \%$ & $50 \%$ & $5 \%$ & $2 \%$ & $1 \%$ & .761 & 4.29 & 178 \\
\hline $\begin{array}{l}\text { I enjoyed the portion of } \\
\text { the course on WebCT }\end{array}$ & $42.7 \%$ & $46.6 \%$ & $6.7 \%$ & $3.4 \%$ & $0.6 \%$ & .779 & 4.28 & 178 \\
\hline $\begin{array}{l}\text { The WebCT portion } \\
\text { stimulated my desire } \\
\text { to learn }\end{array}$ & $28.7 \%$ & $42.1 \%$ & $24.7 \%$ & $3.9 \%$ & $0.6 \%$ & .862 & 3.94 & 178 \\
\hline $\begin{array}{l}\text { I was satisfied with } \\
\text { WebCT in regards to } \\
\text { the quantity of my } \\
\text { learning experience }\end{array}$ & $37 \%$ & $57 \%$ & $5 \%$ & $1 \%$ & $0 \%$ & .616 & 4.30 & 178 \\
\hline $\begin{array}{l}\text { I was satisfied with } \\
\text { WebCT in regards to } \\
\text { the quality of my learn- } \\
\text { ing experience }\end{array}$ & $37 \%$ & $54 \%$ & $8.4 \%$ & $0.6 \%$ & $0 \%$ & .636 & 4.28 & 178 \\
\hline $\begin{array}{l}\text { WebCT portion al- } \\
\text { lowed for social inter- } \\
\text { action }\end{array}$ & $17.4 \%$ & $35.4 \%$ & $27 \%$ & $15.7 \%$ & $4.5 \%$ & 1.090 & 3.46 & 178 \\
\hline $\begin{array}{l}\text { WebCT provided a re- } \\
\text { liable means of com- } \\
\text { munication }\end{array}$ & $33.1 \%$ & $49.4 \%$ & $12 \%$ & $4.5 \%$ & $1 \%$ & .852 & 4.09 & 178 \\
\hline
\end{tabular}

As e-learning has evolved so have the choices involved in the creation and delivery of instruction. With each new generation, more and more features are being added to the e-learning repertoire and it is the responsibility of individual instructors to select the features that will best facilitate learning. According to Ruth DeVillars, "The technology within digital learning technologies should be subservient to the learning. Technology is a tool and a medium, but not the message itself" (2007, p. 1).

\section{Research Methodology}

In order to examine perceived student satisfaction of CMS usage, as well as feature preferences among a predominantly minority population, a study was conducted at a Historically Black University. A minority population was selected because it is currently under represented in the literature. The study involved the creation of hybrid business courses which had a strong emphasis on online learning. The Blackboard CE 6 Learning Management System, which was released in the summer of 2006, was utilized for the delivery of these paper-less hybrid experiences which included: the online submission of all assignments; group work facilitated through a group management tool; a discussion forum; the Web-based delivery of all examinations; WebQuests for project based learning; an online grade book shared by student and instructor; a detailed calendar section with hyperlinks; digital rubric usage for assessment of projects and assignments; diagnostic testing and analysis; weekly announcements; personal mailboxes; and lecture notes and handouts available in PowerPoint, HTML, and MS Word formats. A core business course was targeted 
as the foci of this study, business communications. This course is a requirement for business majors attending the University of Maryland Eastern Shore and is taken primarily by students with sophomore or junior standing.

The study spanned three semesters, beginning in the spring of 2006 and concluding in the spring of 2007. Data was collected through the administration of a detailed 60 question survey distributed in-person in hard copy form to 160 students. The response rate was $88 \%$ with 141 students completing the survey. The survey was designed to assess students' technology access, skills, and usage; prior experiences with e-learning, course delivery preferences, perceived satisfaction with e-learning, and perceptions of, and preferences towards, various e-learning components. The survey contained a mixture of mixed scaled, five point Likert scaled, multiple choice, and open ended questions. The data was entered into and analyzed using SPSS. Descriptive statistics were examined as well as ANOVAs performed.

\section{Results}

In total, 141 students responded to the questionnaire. The majority of participants were minorities, with 75.9\% African American, 6.4\% African, 2.8\% Asian, 4.3\% Caucasian, 7.5\% Hispanic or Caribbean, and $2.1 \%$ claiming other ethnicity. Seventy four percent of the students were between the ages of $20-22$ with $10.1 \%$ reporting being $18-19,10.1 \% 23-25,3.6 \% 26-30$, and $2.1 \%$ over 40 . The number of females responding to the questionnaire slightly outnumbered males, with $55.2 \%$ of the participants female and $44.8 \%$ male. Sixty-six percent of the respondents were college juniors with $11.3 \%$ sophomores, $9.9 \%$ seniors, and $<1 \%$ freshmen. Ninety-three percent of the respondents reported that they were business majors representing Business Administration (51.4\%), Accounting (23.2\%), Marketing (12.8\%), and Business Education (6\%). Students were asked to self-report their GPA's with $6.5 \%$ reporting $2.0-2.3,21 \%$ reporting $2.4-2.6 \%, 25.4$ between 2.7 and $2.9,23.9 \%$ citing 3.0-3.2, $11.6 \%$ reporting $3.3-3.5$, and $11.6 \%$ noting a GPA of $>3.5$.

Participants were asked to self-select a ranking for their level of computer expertise. The majority of participants, $51.4 \%$, responded that they were intermediate computer users. An additional $17.4 \%$ categorized themselves as computer experts, while $29 \%$ said that they had some experience, and $2.2 \%$ considered themselves computer novices (represented in Figure 1). Seventy-four percent of the respondents said that they have studied keyboarding and $82.9 \%$ said that they own a computer. These findings are lower than the $97.8 \%$ rate of ownership reported by Salaway, Katz, and Caruso in 2006 but congruent with the 2005 ECAR study (Caruso \& Kvavik, 2005) where students reported being comfortable with their ability to use core technologies. 


\section{Figure 1: Rank As A Computer User}

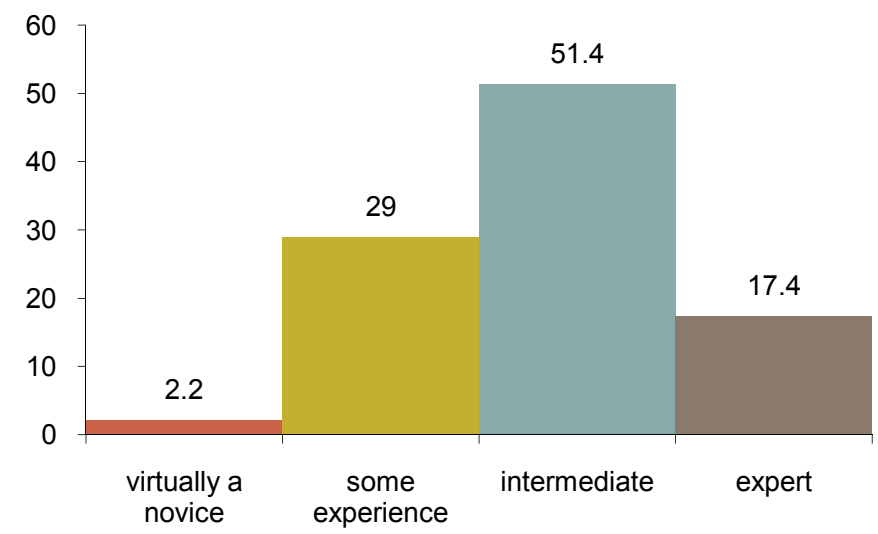

Eighty-nine percent of students said that they have internet access at their home/residence with $93.5 \%$ responding that they go online daily which is lower than the $99.9 \%$ rate of daily internet usage reported in the 2006 ECAR study (Salaway et al., 2006). When asked how much time they spend online per week most students responded that they spend between 3-8 (21\%) or 6-8 $(23.9 \%)$ hours per week which is lower than what was reported in the 2005 ECAR report (Caruso $\&$ Kvavik, 2005). The full distribution is represented in the Figure 2 below.

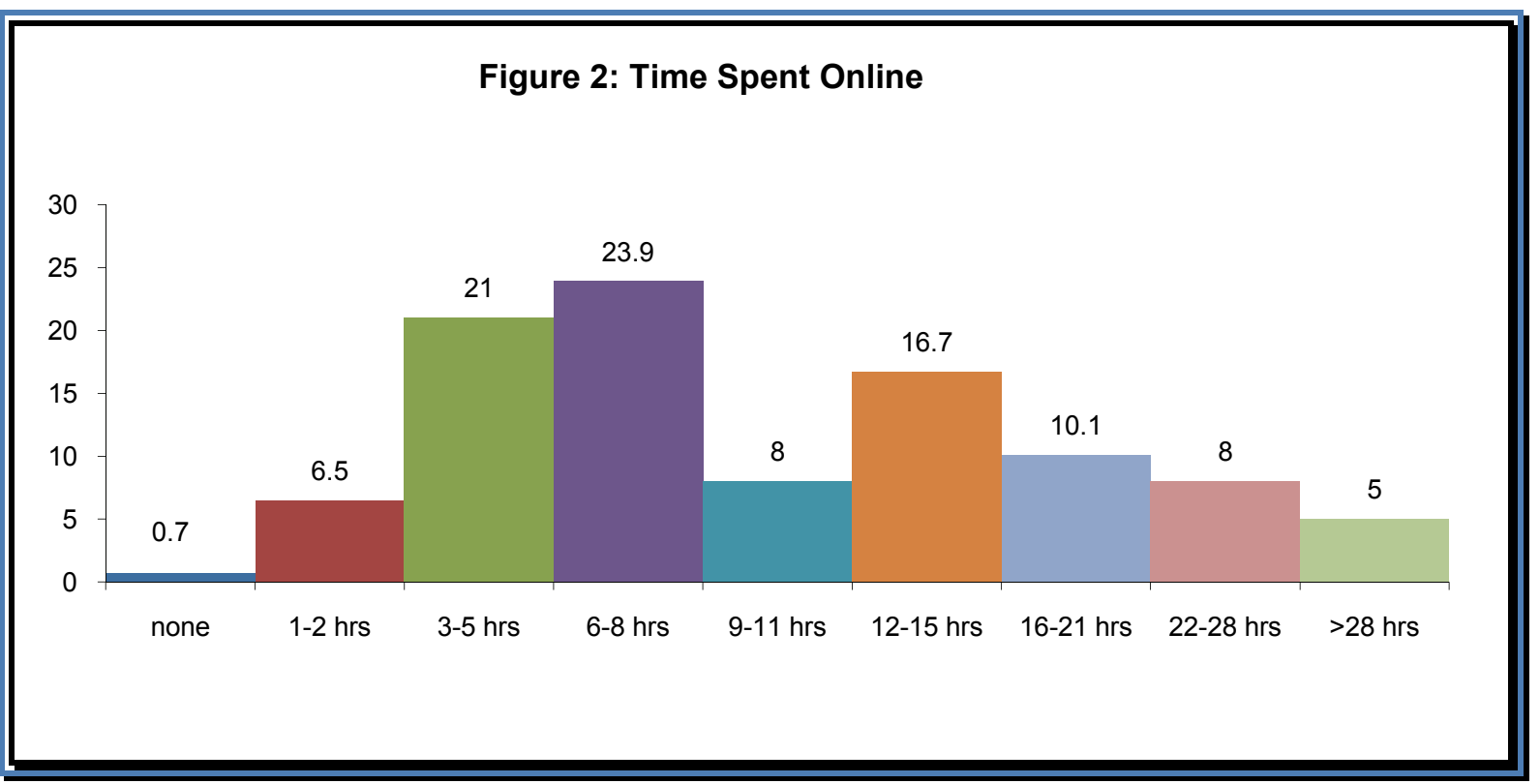

With respect to frequent online activities, the most commonly reported were Email (28.1\%), surfing (24.5\%), and school work (19.4\%) with full distribution represented in Figure 3. These findings are similar to what has been reported in the past two ECAR studies (Caruso \& Kvavik, 2005; Salaway et al., 2006). 


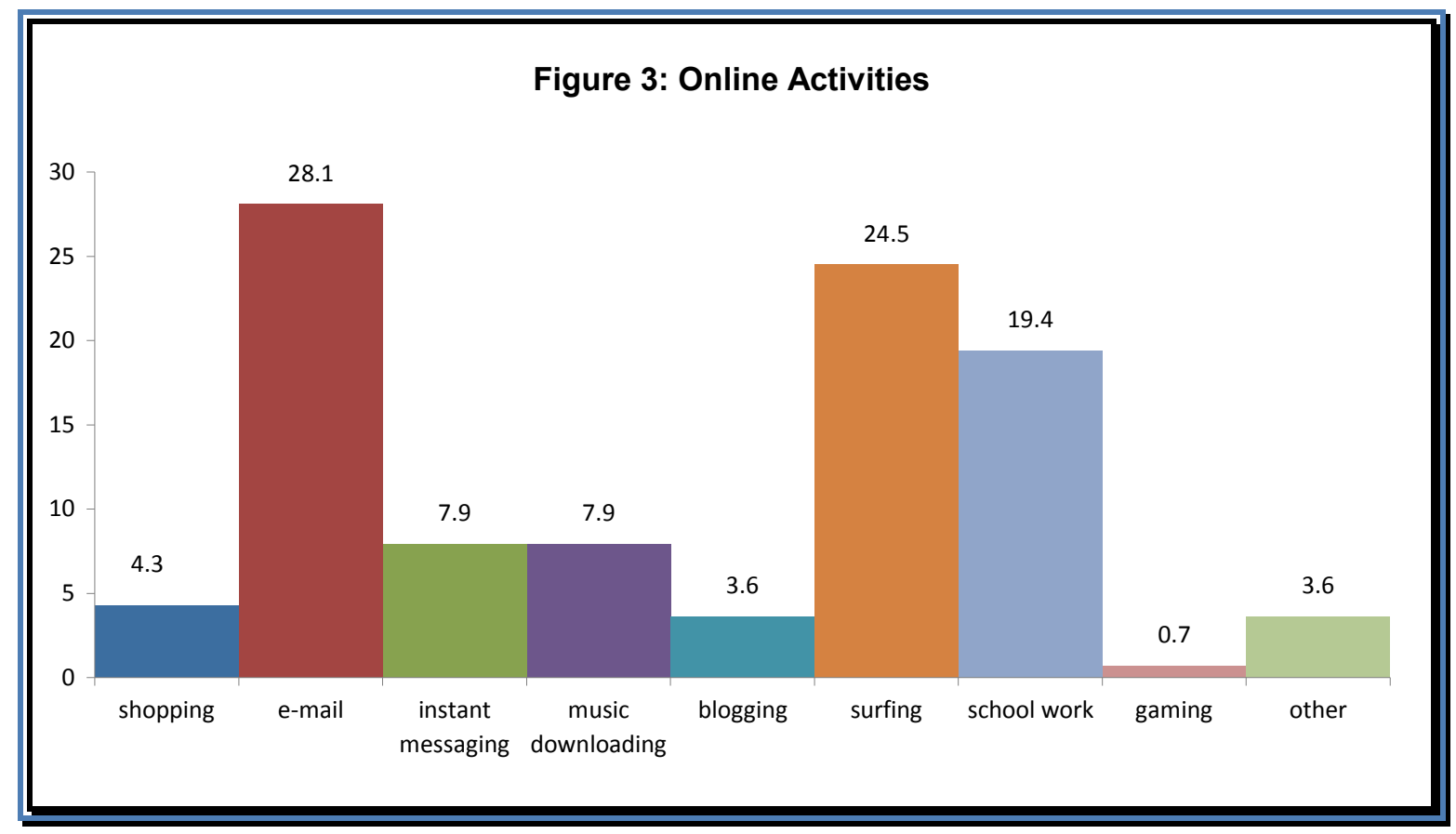

Few students said that they had previous experience taking a fully online course $(78.6 \%)$ and students were mixed as to whether they plan on taking an online course in the future, with $52.9 \%$ saying yes and $47.1 \%$ responding no. These responses are represented in Table 3 . Additionally, most students $(44.8 \%$ ) said that they visited the course Website several times a week, with $25.4 \%$ reporting daily, $21.6 \%$ saying every other week, $6 \%$ monthly, and $<1 \%$ rarely. The reported frequency of visits is represented in Figure 4.

Table 3: Student Responses to Yes or No Questions

\begin{tabular}{|l|l|l|}
\hline \multicolumn{1}{|c|}{ Yes } & No \\
\hline Have you ever taken a fully online course? & $21.4 \%$ & $\mathbf{7 8 . 6 \%}$ \\
\hline $\begin{array}{l}\text { Do you plan to take a fully online course in } \\
\text { the future? }\end{array}$ & $52.9 \%$ & $\mathbf{4 7 . 1 \%}$ \\
\hline \begin{tabular}{l} 
Do you go online daily? \\
\hline
\end{tabular} & $93.5 \%$ & $\mathbf{6 . 5 \%}$ \\
\hline
\end{tabular}


Figure 4: Frequency of Visits

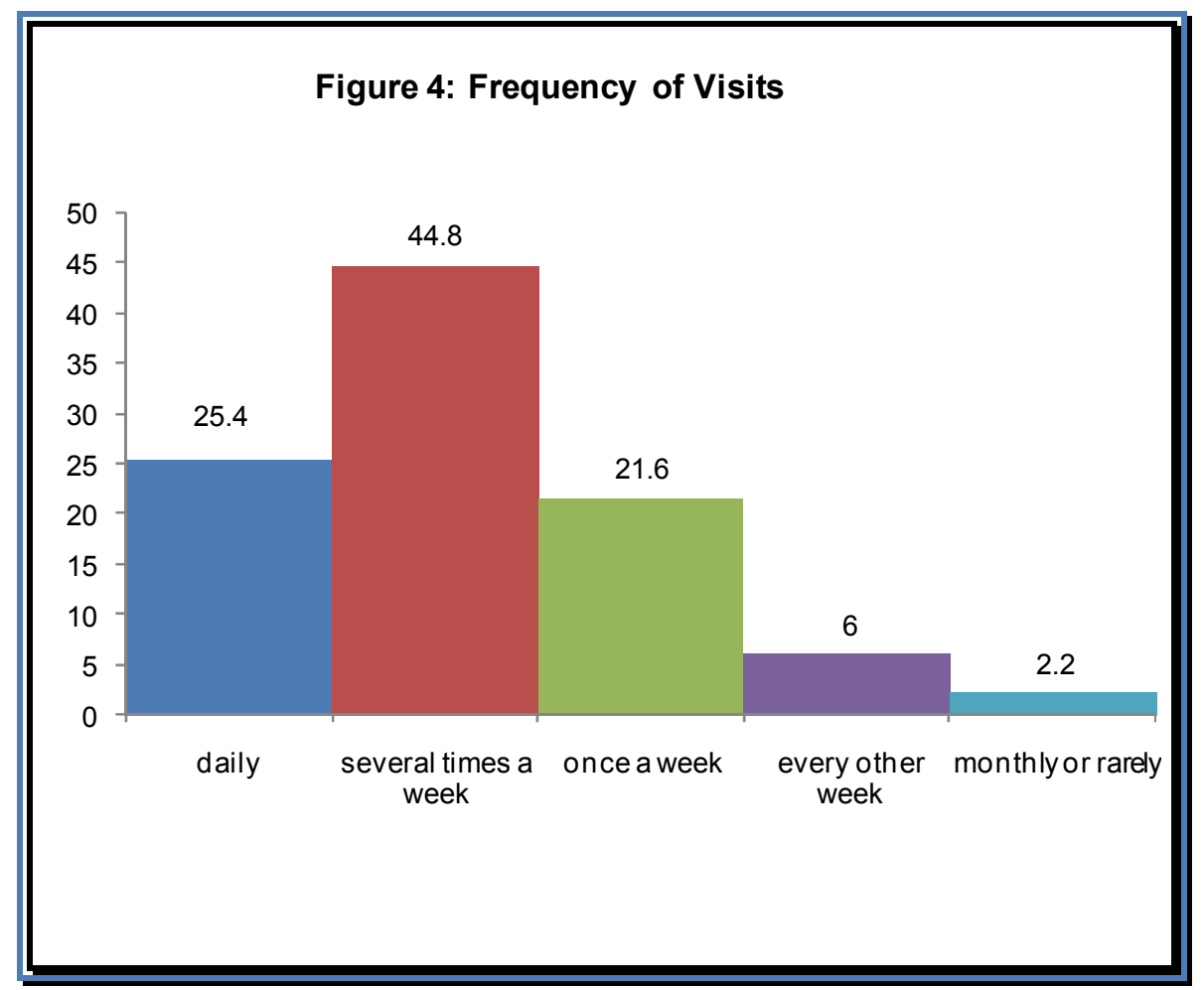

A cluster of questions, represented in Table 4 and Figure 5, looked at preferred delivery methods. When asked if they prefer hybrid courses to traditional face-to-face courses the majority of respondents agreed $(28.1 \%)$, or strongly agreed $(23.0 \%)$, with $25.9 \%$ expressing neutrality. Most respondents said that they prefer face-to-face courses over those that are delivered online $(26.1 \%$ agree, $33.3 \%$ strongly agree, and $29 \%$ neutral/undecided); however, the majority also said that they are interested in taking a fully online course in the future $(23.5 \%$ agree, $28.8 \%$ strongly agree, and $22.0 \%$ neutral/ undecided). These findings compliment earlier studies such as Buzzetto-More and Sweat-Guy (2007), Caruso and Kvavik (2005), Rivera, McAlister, and Rice (2002), and Berube, Murray, and Schultz (1999) who suggest that there exists a greater acceptance of the online mode of instruction as an adjunct to learning. 
Table 4: Student's Delivery/Format Preferences

Response Category: $\mathrm{SA}=$ Strongly Agree, $\mathrm{A}=$ Agree, $\mathrm{N} / \mathrm{U}=$ Neutral/Undecided, $\mathrm{D}=$ Disagree, $\mathrm{SD}=\mathrm{Strongly}$ Disagree traditional face-to-face

SA

A $\quad \mathbf{N} / \mathbf{U}$

D SD

Mean STD

$\mathbf{N}$

classes.

$\begin{array}{llllllll}23 \% & 28.1 \% & 25.9 \% & 11.9 \% & 11.1 \% & 3.40 & 1.271 & 135\end{array}$

I am interested in taking a

fully online course in the

$28.8 \% \quad 23.5 \% \quad 22 \% \quad 12.1 \% \quad 13.6 \% \quad 3.42 \quad 1.376$

132

future.

I would rather take a

course that meets in person

than one that meets online.

$\begin{array}{llllllll}33.3 \% & 26.1 \% & 29 \% & 5.8 \% & 5.8 \% & 3.75 & 1.151 & 138\end{array}$

Figure 5: Delivery Preferences

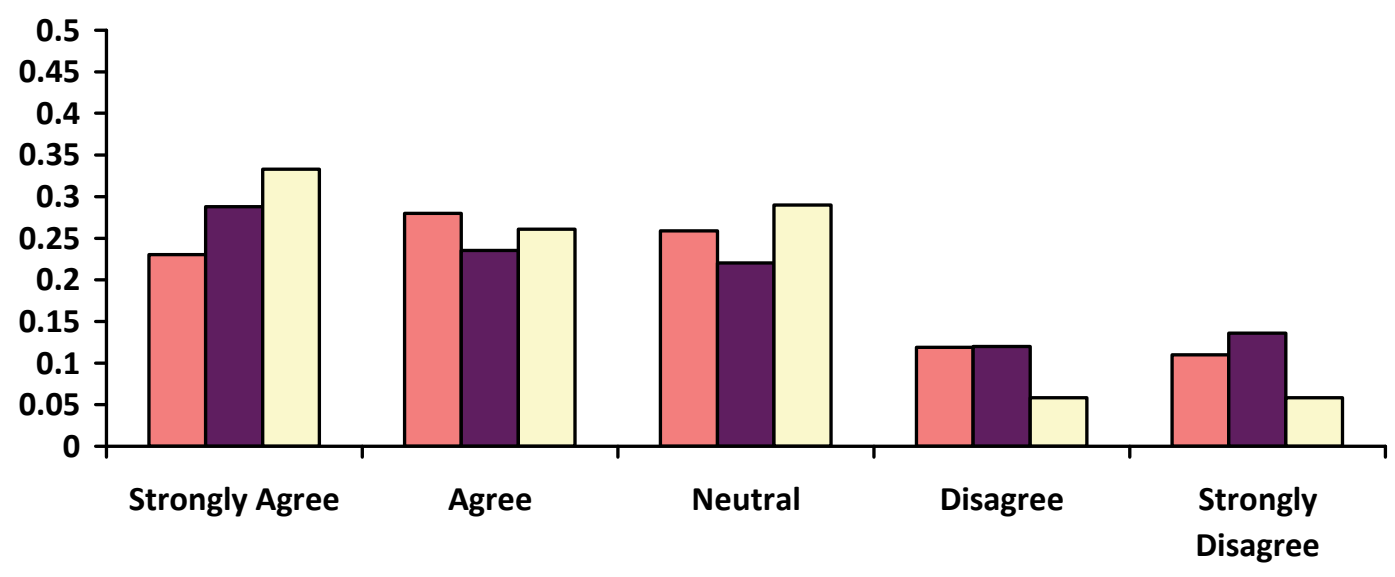

$\square$ Prefer Hybrid $\square$ Interested In Fully Online $\square$ Prefer In-Person

Proponents of web-based teaching and learning suggest that providing useful and relevant information about the course content correlates positively with student satisfaction and participation (Sanders \& Morrison-Shetlar, 2002). Overall, students were satisfied with the course Website (47.9\% agree and $42.9 \%$ strongly agree), found the course Website to be a helpful resource $(50 \%$ agree and $40 \%$ strongly agree), used the course Website to understand course information (39.1\% agree and $27.0 \%$ strongly agree), and regularly used the course Website to answer their questions (40.6\% agree and $26.1 \%$ strongly agree). Most students felt that course Websites enhance learning (35.0\% agree and $25.7 \%$ strongly agree), should be added to all of their courses ( $44.2 \%$ agree and $31.2 \%$ strongly agree), and will play an increasingly more important role in college education in the future (40.6\% agree and $44.2 \%$ strongly agree). These findings are depicted in Table 5 and Figure 6. 
Table 5: Student's Perceived Satisfaction

Response Category: $\mathrm{SA}=$ Strongly Agree, $\mathrm{A}=$ Agree, $\mathrm{N} / \mathrm{U}=$ Neutral/Undecided, $\mathrm{D}=$ Disagree, $\mathrm{SD}=$ Strongly Disagree

\begin{tabular}{lcccccccc}
\hline & SA & A & N/U & D & SD & Mean & STD & N \\
$\begin{array}{l}\text { Overall I was satisfied } \\
\text { with the course Website. }\end{array}$ & $42.9 \%$ & $47.9 \%$ & $8.6 \%$ & $0.7 \%$ & $0 \%$ & 4.32 & .692 & 140 \\
$\begin{array}{l}\text { I found the course Website } \\
\text { to be a helpful resource. }\end{array}$ & $40.0 \%$ & $50.0 \%$ & $9.3 \%$ & $0.7 \%$ & $0 \%$ & 4.29 & .692 & 140 \\
$\begin{array}{l}\text { I used the course Website } \\
\text { to help me understand } \\
\text { course information. }\end{array}$ & $37.0 \%$ & $39.1 \%$ & $16.7 \%$ & $5.8 \%$ & $1.4 \%$ & 4.04 & .950 & 138 \\
$\begin{array}{l}\text { I regularly used the course } \\
\text { Website to answer my }\end{array}$ & $26.1 \%$ & $40.6 \%$ & $23.2 \%$ & $7.2 \%$ & $2.9 \%$ & 3.80 & 1.005 & 138 \\
$\begin{array}{l}\text { questions. } \\
\text { I believe that course Web- } \\
\text { sites enhance learning. }\end{array}$ & $25.7 \%$ & $35 \%$ & $26.4 \%$ & $9.3 \%$ & $3.6 \%$ & 3.70 & 1.064 & 140 \\
$\begin{array}{l}\text { I would like to see course } \\
\text { Websites added to all of } \\
\text { my courses. }\end{array}$ & $44.1 \%$ & $25 \%$ & $14 \%$ & $6.6 \%$ & $10.3 \%$ & 3.86 & 1.329 & 136 \\
$\begin{array}{l}\text { I believe that course Web- } \\
\text { sites will play an important } \\
\text { role in college education in } \\
\text { the future. }\end{array}$ & $44.2 \%$ & $40.6 \%$ & $8.7 \%$ & $5.1 \%$ & $1.4 \%$ & 4.21 & .908 & 138 \\
\hline
\end{tabular}

Figure 6: Satisfaction

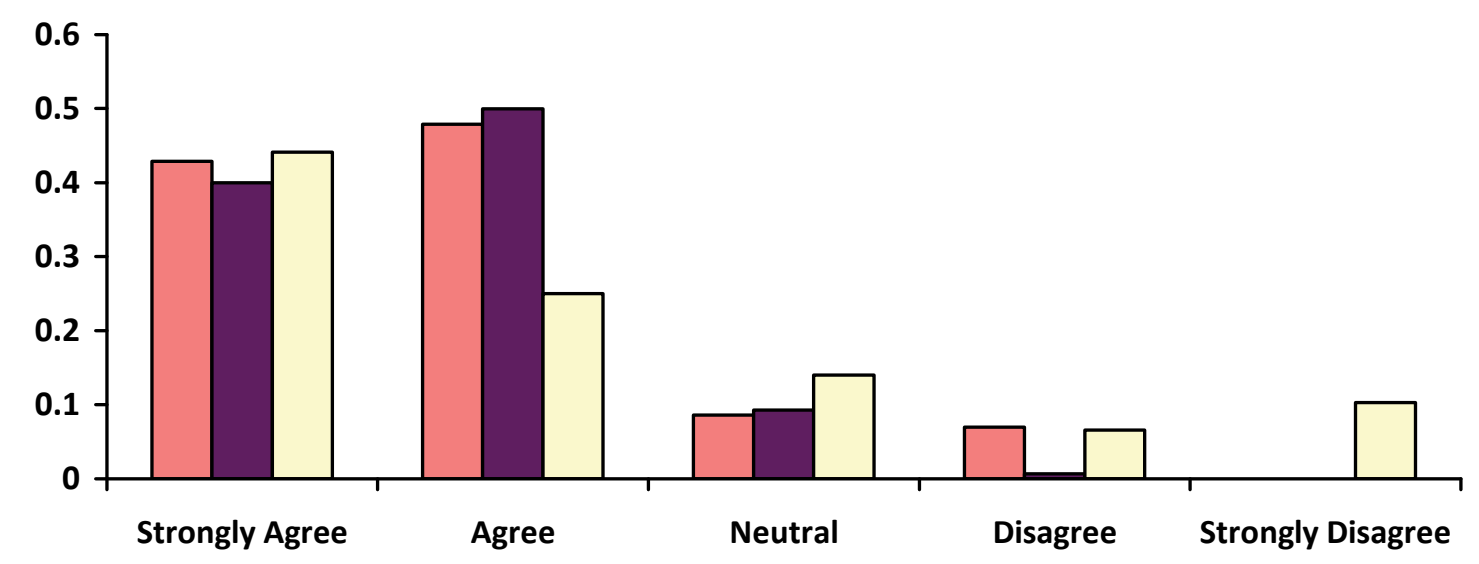

$\square$ Overall Satisfaction $\square$ Helpful Resource $\square$ Want Added to All

E-learning has been linked to the stimulating of communications and interactions (Carswell, Thomas, Petre, Price, \& Richards, 2000; Lesh, Guffey, \& Rampp, 2000). As a result, a series of 
questions dealt with communications and collaborations and the findings complimented the larger literature. Illustrated in Table 6, the students replied that the course Website helped to create a sense of community (30.9\% agree, $21.3 \%$ strongly agree, and $30.9 \%$ neutral/undecided), increased student-instructor interactions (40.9\% agree and $22.6 \%$ strongly agree), and increased the volume of interactions (38.8\% agree and $23.1 \%$ strongly agree).

Table 6: Student's Perceptions of Interactions

Response Category: $\mathrm{SA}=$ Strongly Agree, $\mathrm{A}=$ Agree, $\mathrm{N} / \mathrm{U}=$ Neutral/Undecided, $\mathrm{D}=$ Disagree, $\mathrm{SD}=\mathrm{Strongly}$ Disagree

\begin{tabular}{|c|c|c|c|c|c|c|c|}
\hline SA & $\mathbf{A}$ & $\mathbf{N} / \mathbf{U}$ & D & SD & Mean & STD & $\mathbf{N}$ \\
\hline $21.3 \%$ & $30.9 \%$ & $30.9 \%$ & $11 \%$ & $5.9 \%$ & 3.51 & 1.122 & 136 \\
\hline $22.6 \%$ & $40.9 \%$ & $16.1 \%$ & $13.1 \%$ & $7.3 \%$ & 3.58 & 1.186 & 137 \\
\hline $23.1 \%$ & $38.8 \%$ & $23.9 \%$ & $9 \%$ & $5.2 \%$ & 3.66 & 1.091 & 134 \\
\hline $15.9 \%$ & $29.7 \%$ & $38.4 \%$ & $12.3 \%$ & $3.6 \%$ & 3.42 & 1.017 & 138 \\
\hline
\end{tabular}

Overall, most students said that they were satisfied with the content available on the course Website $(51.1 \%$ agree and $33.1 \%$ strongly agree); however, in order to conduct a more in-depth analysis a variety of features were examined. Most students were satisfied with the online lecture notes (89.5\% agree/strongly agree), considered them a valuable resource (79.6\% agree/strongly agree), found them easy to print ( $75.2 \%$ agree/strongly agree), and were glad they were delivered in PowerPoint format (74.8\%). The hyperlinked calendar section was frequently visited $(68.2 \%$ agree/strongly agree) and was considered a valuable resource (78.1\% agree/strongly agree). Students considered the links on the course Website to be a valuable resource $(72.7 \%$ agree/strongly agree) and visited them regularly (54.2\% agree/strongly agree and $29.5 \%$ neutral/undecided). Students responded that the course Website was a great place for instructors to place handouts with $34.6 \%$ saying agree and $46.3 \%$ strongly agreeing. These findings, which are fully represented in Table 7.1, are in line with research conducted by Caruso and Salaway (2007) and Wernet, Olliges, and Delicath (2000) who found that course Websites have proved to be an effective means of delivering learning materials, with students responding positively to the quality resources they make available. 
Table 7.1: Student's Perceptions of Individual Features

Response Category: $\mathrm{SA}=$ Strongly Agree, $\mathrm{A}=$ Agree, $\mathrm{N} / \mathrm{U}=$ Neutral/Undecided, $\mathrm{D}=$ Disagree, $\mathrm{SD}=\mathrm{Strongly}$ Disagree

\begin{tabular}{|c|c|c|c|c|c|c|c|}
\hline $\mathbf{S A}$ & $\mathbf{A}$ & $\mathbf{N} / \mathbf{U}$ & D & SD & Mean & STD & $\mathbf{N}$ \\
\hline $33.1 \%$ & $51.1 \%$ & $10.8 \%$ & $2.9 \%$ & $2.2 \%$ & 4.10 & .862 & 139 \\
\hline $40.1 \%$ & $39.4 \%$ & $13.1 \%$ & $5.1 \%$ & $2.2 \%$ & 4.10 & .965 & 137 \\
\hline $41.6 \%$ & $38 \%$ & $15.3 \%$ & $3.6 \%$ & $1.5 \%$ & 4.15 & .912 & 137 \\
\hline $36.1 \%$ & $39.1 \%$ & $15.8 \%$ & $7.5 \%$ & $1.5 \%$ & 4.01 & .981 & 133 \\
\hline $37 \%$ & $37.8 \%$ & $20 \%$ & $4.4 \%$ & $0.7 \%$ & 4.06 & .904 & 135 \\
\hline $34.1 \%$ & $34.1 \%$ & $16.7 \%$ & $12.3 \%$ & $2.9 \%$ & 3.84 & 1.116 & 138 \\
\hline $40.9 \%$ & $37.2 \%$ & $13.9 \%$ & $7.3 \%$ & $0.7 \%$ & 4.10 & .949 & 137 \\
\hline $30.1 \%$ & $42.6 \%$ & $23.5 \%$ & $2.2 \%$ & $1.5 \%$ & 3.98 & .873 & 136 \\
\hline $24.2 \%$ & $30.3 \%$ & $29.5 \%$ & $12.1 \%$ & $3.8 \%$ & 3.59 & 1.098 & 132 \\
\hline $46.3 \%$ & $34.6 \%$ & $11.8 \%$ & $4.4 \%$ & $2.9 \%$ & 4.17 & 1.000 & 136 \\
\hline
\end{tabular}

I was satisfied with the content available on the course Website.

\begin{tabular}{|c|c|c|c|c|c|c|c|}
\hline $\mathbf{S A}$ & $\mathbf{A}$ & $\mathbf{N} / \mathbf{U}$ & D & SD & Mean & STD & $\mathbf{N}$ \\
\hline $33.1 \%$ & $51.1 \%$ & $10.8 \%$ & $2.9 \%$ & $2.2 \%$ & 4.10 & .862 & 139 \\
\hline $40.1 \%$ & $39.4 \%$ & $13.1 \%$ & $5.1 \%$ & $2.2 \%$ & 4.10 & .965 & 137 \\
\hline $41.6 \%$ & $38 \%$ & $15.3 \%$ & $3.6 \%$ & $1.5 \%$ & 4.15 & .912 & 137 \\
\hline $36.1 \%$ & $39.1 \%$ & $15.8 \%$ & $7.5 \%$ & $1.5 \%$ & 4.01 & .981 & 133 \\
\hline $37 \%$ & $37.8 \%$ & $20 \%$ & $4.4 \%$ & $0.7 \%$ & 4.06 & .904 & 135 \\
\hline $34.1 \%$ & $34.1 \%$ & $16.7 \%$ & $12.3 \%$ & $2.9 \%$ & 3.84 & 1.116 & 138 \\
\hline $40.9 \%$ & $37.2 \%$ & $13.9 \%$ & $7.3 \%$ & $0.7 \%$ & 4.10 & .949 & 137 \\
\hline $30.1 \%$ & $42.6 \%$ & $23.5 \%$ & $2.2 \%$ & $1.5 \%$ & 3.98 & .873 & 136 \\
\hline $24.2 \%$ & $30.3 \%$ & $29.5 \%$ & $12.1 \%$ & $3.8 \%$ & 3.59 & 1.098 & 132 \\
\hline $46.3 \%$ & $34.6 \%$ & $11.8 \%$ & $4.4 \%$ & $2.9 \%$ & 4.17 & 1.000 & 136 \\
\hline
\end{tabular}

I was satisfied with the online lecture notes included on the course Website.

The online lecture notes were a valuable resource.

\begin{tabular}{|c|c|c|c|c|c|c|c|}
\hline $\mathbf{S A}$ & $\mathbf{A}$ & $\mathbf{N} / \mathbf{U}$ & D & SD & Mean & STD & $\mathbf{N}$ \\
\hline $33.1 \%$ & $51.1 \%$ & $10.8 \%$ & $2.9 \%$ & $2.2 \%$ & 4.10 & .862 & 139 \\
\hline $40.1 \%$ & $39.4 \%$ & $13.1 \%$ & $5.1 \%$ & $2.2 \%$ & 4.10 & .965 & 137 \\
\hline $41.6 \%$ & $38 \%$ & $15.3 \%$ & $3.6 \%$ & $1.5 \%$ & 4.15 & .912 & 137 \\
\hline $36.1 \%$ & $39.1 \%$ & $15.8 \%$ & $7.5 \%$ & $1.5 \%$ & 4.01 & .981 & 133 \\
\hline $37 \%$ & $37.8 \%$ & $20 \%$ & $4.4 \%$ & $0.7 \%$ & 4.06 & .904 & 135 \\
\hline $34.1 \%$ & $34.1 \%$ & $16.7 \%$ & $12.3 \%$ & $2.9 \%$ & 3.84 & 1.116 & 138 \\
\hline $40.9 \%$ & $37.2 \%$ & $13.9 \%$ & $7.3 \%$ & $0.7 \%$ & 4.10 & .949 & 137 \\
\hline $30.1 \%$ & $42.6 \%$ & $23.5 \%$ & $2.2 \%$ & $1.5 \%$ & 3.98 & .873 & 136 \\
\hline $24.2 \%$ & $30.3 \%$ & $29.5 \%$ & $12.1 \%$ & $3.8 \%$ & 3.59 & 1.098 & 132 \\
\hline $46.3 \%$ & $34.6 \%$ & $11.8 \%$ & $4.4 \%$ & $2.9 \%$ & 4.17 & 1.000 & 136 \\
\hline
\end{tabular}

The lecture notes were easy to print.

I liked that the lecture notes were available in PowerPoint.

I regularly visited the calendar section.

I found the calendar section to be a valuable resource.

I found the links contained on the course Website valuable.

I regularly visited the links contained on the course Website.

\begin{tabular}{|c|c|c|c|c|c|c|c|}
\hline $\mathbf{S A}$ & $\mathbf{A}$ & $\mathbf{N} / \mathbf{U}$ & D & SD & Mean & STD & $\mathbf{N}$ \\
\hline $33.1 \%$ & $51.1 \%$ & $10.8 \%$ & $2.9 \%$ & $2.2 \%$ & 4.10 & .862 & 139 \\
\hline $40.1 \%$ & $39.4 \%$ & $13.1 \%$ & $5.1 \%$ & $2.2 \%$ & 4.10 & .965 & 137 \\
\hline $41.6 \%$ & $38 \%$ & $15.3 \%$ & $3.6 \%$ & $1.5 \%$ & 4.15 & .912 & 137 \\
\hline $36.1 \%$ & $39.1 \%$ & $15.8 \%$ & $7.5 \%$ & $1.5 \%$ & 4.01 & .981 & 133 \\
\hline $37 \%$ & $37.8 \%$ & $20 \%$ & $4.4 \%$ & $0.7 \%$ & 4.06 & .904 & 135 \\
\hline $34.1 \%$ & $34.1 \%$ & $16.7 \%$ & $12.3 \%$ & $2.9 \%$ & 3.84 & 1.116 & 138 \\
\hline $40.9 \%$ & $37.2 \%$ & $13.9 \%$ & $7.3 \%$ & $0.7 \%$ & 4.10 & .949 & 137 \\
\hline $30.1 \%$ & $42.6 \%$ & $23.5 \%$ & $2.2 \%$ & $1.5 \%$ & 3.98 & .873 & 136 \\
\hline $24.2 \%$ & $30.3 \%$ & $29.5 \%$ & $12.1 \%$ & $3.8 \%$ & 3.59 & 1.098 & 132 \\
\hline $46.3 \%$ & $34.6 \%$ & $11.8 \%$ & $4.4 \%$ & $2.9 \%$ & 4.17 & 1.000 & 136 \\
\hline
\end{tabular}

The course Website is a great place for the instructor to place handouts.

With respect to usage of the CMS as a communication tool 53.1\% said that they emailed the instructor through the course Website, and 54.6\% regularly checked their course mailbox. The discussion section was a popular feature with $69.3 \%$ agreeing/ strongly agreeing that it was regularly used, $78.9 \%$ saying it was easy, $68.2 \%$ agreeing/strongly agreeing that it helped them understand course content, $74.4 \%$ saying it was a great way to interact with fellow students, $71.6 \%$ saying that it was a great way to interact with instructors, and $70.6 \%$ saying that they were glad that discussion section participation was factored into their final grade. Forty four percent of the respondents said that they would rather do an assignment than a discussion while $26.3 \%$ expressed neutrality and $39.2 \%$ disagreement. These findings, represented in Table 7.2, compliment the preponderance of research, which has suggested that online communications increases interaction among students and between students and instructors (Buzzetto-More \& Sweat-Guy, 2006; Carswell et al., 2000; Lesh et al., 2000). 
Table 7.2: Student's Perceptions of Individual Features

Response Category: $\mathrm{SA}=$ Strongly Agree, $\mathrm{A}=$ Agree, $\mathrm{N} / \mathrm{U}=$ Neutral/Undecided, $\mathrm{D}=$ Disagree, $\mathrm{SD}=$ Strongly Disagree

\begin{tabular}{|c|c|c|c|c|c|c|c|}
\hline $\mathbf{S A}$ & $\mathbf{A}$ & $\mathbf{N} / \mathbf{U}$ & D & SD & Mean & STD & $\mathbf{N}$ \\
\hline $29.7 \%$ & $23.4 \%$ & $20.3 \%$ & $16.4 \%$ & $10.2 \%$ & 3.46 & 1.339 & 128 \\
\hline $28.8 \%$ & $25.8 \%$ & $13.6 \%$ & $15.9 \%$ & $15.9 \%$ & 3.36 & 1.447 & 132 \\
\hline $32.8 \%$ & $36.5 \%$ & $22.6 \%$ & $5.8 \%$ & $2.2 \%$ & 3.92 & .993 & 137 \\
\hline $40.9 \%$ & $38 \%$ & $16.8 \%$ & $2.9 \%$ & $1.5 \%$ & 4.14 & .901 & 137 \\
\hline $30.4 \%$ & $37.8 \%$ & $23 \%$ & $5.9 \%$ & $3 \%$ & 3.87 & 1.013 & 135 \\
\hline $40.1 \%$ & $34.3 \%$ & $21.2 \%$ & $2.9 \%$ & $1.5 \%$ & 4.09 & .927 & 137 \\
\hline $34.3 \%$ & $37.3 \%$ & $20.1 \%$ & $5.2 \%$ & $3 \%$ & 3.95 & 1.014 & 134 \\
\hline $30.6 \%$ & $29.9 \%$ & $24.6 \%$ & $11.9 \%$ & $3 \%$ & 3.73 & 1.112 & 134 \\
\hline $39.7 \%$ & $30.9 \%$ & $20.6 \%$ & $4.4 \%$ & $4.4 \%$ & 3.97 & 1.088 & 136 \\
\hline $19.7 \%$ & $24.8 \%$ & $28.3 \%$ & $14.6 \%$ & $14.6 \%$ & 3.20 & 1.318 & 137 \\
\hline
\end{tabular}

signment than a discussion.

I emailed the instructor through the course Website.

I regularly checked my mailbox.

I regularly used the discussion section.

I found the discussion section easy to use.

The discussions helped me better understand course content.

The discussion section is a great way to interact with my fellow classmates.

The discussion section is a great way to interact with the instructor.

The discussion section helped me to ask and answer questions.

I am glad the discussion section was factored into my final grade.

I would rather do an as-

The most popular feature noted in this study was the assignment section with $79.8 \%$ agreeing/ strongly agreeing that they enjoyed submitting assignments online, $66.6 \%$ agreeing/strongly agreeing that they prefer the online submission of assignments, $81.8 \%$ agreeing/strongly agreeing that the online submission of assignments was simple, and $81.7 \%$ agreeing/strongly agreeing that the online submission of assignments was convenient. Most students $(87.5 \%)$ checked the assignment section for their grades; an overwhelming 99.1\% said that they liked that they had the ability to check assignment grades online; $86.2 \%$ read the instructor comments/feedback associated with assignments. These findings, illustrated in Table 7.3, reflect the larger literature which has reported strong student preferences towards online assignment usage (Barrack, 2005; Salaway \& Caruso, 2007. 
Table 7.3: Student's Perceptions of Individual Features

Response Category: SA= Strongly Agree, $A=$ Agree, $N / U=$ Neutral/Undecided, $D=$ Disagree, $S D=$ Strongly Disagree

$$
\begin{array}{llllllll}
\text { SA } & A & \text { N/U } & \text { D } & \text { SD } & \text { Mean } & \text { STD } & \text { N }
\end{array}
$$

\section{D}

I enjoyed submitting my

assignments online.

$\begin{array}{lllllllll}39.9 \% & 39.9 \% & 10.9 \% & 5.8 \% & 3.6 \% & 4.07 & 1.034 & 138 \\ 39.1 \% & 27.5 \% & 17.4 \% & 10.9 \% & 5.1 \% & 3.85 & 1.202 & 138 \\ & & & & & & & \\ 43.1 \% & 38.7 \% & 10.9 \% & 3.6 \% & 3.6 \% & 4.14 & 1.001 & 137 \\ & & & & & & & \\ 44.5 \% & 37.2 \% & 10.9 \% & 4.4 \% & 2.9 \% & 4.16 & .987 & 137 \\ & & & & & & & \\ 48.5 \% & 39 \% & 8.1 \% & 2.9 \% & 1.5 \% & 4.30 & .855 & 136 \\ & & & & & & & \\ 50.4 \% & 38.7 \% & 8.8 \% & 0.7 \% & 1.5 \% & 4.36 & .793 & 137 \\ & & & & & & & \\ 42 \% & 44.2 \% & 9.4 \% & 2.2 \% & 2.2 \% & 4.22 & .869 & 138\end{array}$

I prefer the online submission of assignments.

I found the online submission of assignments simple.

I found the online submission of assignments convenient.

I checked the assignment section for my grades.

I liked that I had the ability to check my assignment grades online.

I read the instructor comments on my assignments.

$\begin{array}{lllll}42 \% & 44.2 \% & 9.4 \% & 2.2 \% & 2.2 \%\end{array} \quad 4.22$

38

38

Derouza and Fleming (2003) reported positive findings from online student assessments. When asked about assessments $72.8 \%$ of participants agreed/strongly agreed that online exams were

\begin{tabular}{|c|c|c|c|c|c|c|c|c|}
\hline & SA & $\mathbf{A}$ & $\mathbf{N} / \mathbf{U}$ & D & SD & Mean & STD & $\mathbf{N}$ \\
\hline $\begin{array}{l}\text { I took the online } \\
\text { quizzes/exams. }\end{array}$ & $60.1 \%$ & $31.2 \%$ & $8.7 \%$ & $0 \%$ & $0 \%$ & 4.51 & .653 & 138 \\
\hline $\begin{array}{l}\text { I found taking exams } \\
\text { online convenient. }\end{array}$ & $46.3 \%$ & $26.5 \%$ & $12.5 \%$ & $9.6 \%$ & $5.1 \%$ & 3.99 & 1.202 & 136 \\
\hline $\begin{array}{l}\text { I found the exam section } \\
\text { easy to use. }\end{array}$ & $44.9 \%$ & $34.6 \%$ & $10.3 \%$ & $5.9 \%$ & $4.4 \%$ & 4.10 & 1.088 & 136 \\
\hline $\begin{array}{l}\text { The quiz/exam worked } \\
\text { during my visit. }\end{array}$ & $49.6 \%$ & $35.6 \%$ & $9.6 \%$ & $3 \%$ & $2.2 \%$ & 4.27 & .918 & 135 \\
\hline $\begin{array}{l}\text { I liked that I received an } \\
\text { instant grade after taking } \\
\text { an online quiz/exam. }\end{array}$ & $54.1 \%$ & $35.6 \%$ & $8.9 \%$ & $1.5 \%$ & $0 \%$ & 4.42 & .918 & 135 \\
\hline $\begin{array}{l}\text { I prefer to take my quiz- } \\
\text { zes/exams in person. }\end{array}$ & $28.7 \%$ & $16.9 \%$ & $27.2 \%$ & $13.2 \%$ & $14 \%$ & 3.33 & 1.383 & 136 \\
\hline
\end{tabular}
convenient, worked during their visits $(85.2 \%)$ and were easy to use $(79.5 \%)$. The students liked that they received an instant grade and feedback after taking an exam (89.7\%) and only $45.6 \%$ of students said that they prefer to take quizzes and exams in person with $27.2 \%$ neutrality. These findings are represented in Table 7.4 below.

\section{Table 7.4: Student's Perceptions of Individual Features}

Response Category: $\mathrm{SA}=$ Strongly Agree, $\mathrm{A}=$ Agree, $\mathrm{N} / \mathrm{U}=$ Neutral/Undecided, $\mathrm{D}=$ Disagree, $\mathrm{SD}=\mathrm{Strongly}$ Disagree 
A number of one-way ANOVAs were run and interesting findings were revealed. The areas examined included:

- whether rank as a computer user correlated with plans to take an online course in the future,

- if frequency of usage related to satisfaction,

- whether desire to see course Websites added to all courses related to the opinion that course Websites will play a more important role in higher education in the future,

- whether preference towards in person courses related to satisfaction,

- if going online daily related to interest in taking a fully online course in the future,

- whether previous experience with a fully online course related to plans to take an online course in the future, and

- gender related to interest in taking an online course in the future.

According to the ANOVAs when $\mathrm{p}$ values of greater than .05 were considered the following relationships were revealed:

- rank as a computer user and plan to take a fully online course in the future,

- frequency of visits to the course Website with overall satisfaction,

- preference for in person courses and course Website satisfaction,

- amount of time spent online with plans to take a fully online course in the future, and

- gender with plans to take and online course in the future.

These findings are in agreement with similar studies that have observed differences in computerrelated experience as a key factor (Buzzetto-More \& Sweat-Guy, 2006). Additionally, a number of studies have found that gender relates to e-learning preferences (Buzzetto-More \& Sweat-Guy, 2006; Sanders \& Morrison-Shetlar, 2002).

No relationships $(\mathrm{p}<.05)$ existed that indicated a relationship with desire to have course Websites added to all courses and either overall satisfaction or the belief that course Websites will play a more important role in the future. Additionally, previous experience taking an online course did not relate to plans to take an online course in the future. Table 8 represents the findings.

Table 8: One-Way ANOVA Comparing Mean Differences

\begin{tabular}{llll}
\hline $\begin{array}{l}\text { Dependent } \\
\text { Variable }\end{array}$ & F & Sig. \\
\hline $\begin{array}{l}\text { Do you plan to take } \\
\text { an online course in } \\
\text { the future? }\end{array}$ & Rank as a computer user. & .264 & $\mathbf{. 6 0 8}$ \\
$\begin{array}{l}\text { How often did you } \\
\text { visit the course Web- } \\
\text { site? }\end{array}$ & Overall, I was satisfied with the course Website. & & \\
\hline $\begin{array}{l}\text { I would rather take a } \\
\text { course that meets in } \\
\text { person than one that } \\
\text { meets online. }\end{array}$ & Overall, I was satisfied with the course Website & 1.746 & $\mathbf{. 1 6 1}$ \\
\hline $\begin{array}{l}\text { I would like to see } \\
\text { course Websites } \\
\text { added to all my } \\
\text { courses. }\end{array}$ & $\begin{array}{l}\text { I believe that course Websites will play an impor- } \\
\text { tant role in college education in the future. }\end{array}$ & $\mathbf{. 0 0 0}$ \\
\hline
\end{tabular}




\begin{tabular}{|c|c|c|c|}
\hline $\begin{array}{l}\text { I would rather take a } \\
\text { course that meets in } \\
\text { person than one that } \\
\text { meets online. }\end{array}$ & Overall, I was satisfied with the course Website. & .429 & .787 \\
\hline $\begin{array}{l}\text { Do you go online } \\
\text { daily? }\end{array}$ & $\begin{array}{l}\text { Do you plan to take a fully online course in the } \\
\text { future? }\end{array}$ & 2.828 & .095 \\
\hline $\begin{array}{l}\text { Have you ever taken } \\
\text { a fully online course? }\end{array}$ & $\begin{array}{l}\text { Do you plan to take a fully online course in the } \\
\text { future? }\end{array}$ & 10.946 & .001 \\
\hline Gender & $\begin{array}{l}\text { Do you plan to take a fully online course in the } \\
\text { future? }\end{array}$ & .001 & .969 \\
\hline
\end{tabular}

\section{Contributions}

This study provides research on a population that has previously not received sufficient focus and which is largely neglected in the literature. This paper builds on the findings of a number of studies that have examined student e-learning experiences, perceptions, and preferences at majority institutions. It is expansive in its scope by looking specifically at student perceptions of individual course components.

Responses to this study have shown that students perceive the use of course Websites as a course enhancement positively, which mirrors the findings of similar studies conducted at majority institutions. These results are being used as the university refines its formal e-learning strategy and model for excellence.

\section{Limitations of This Study}

The most significant limitation of this study is that it focused solely on business students. In order to rectify this limitation, the study is being expanded to include a student population of over 4,000 representing a wide variety of ages and disciplines.

\section{Summary and Future Research}

The results of this paper suggest that the use of hybrid learning methodologies in higher education increases students' course satisfaction, whereas students found course Websites to be helpful resources $(90 \%)$ that will have an impact on higher education in the future $(85 \%)$. These results were in line with the findings of similar studies conducted at majority institutions and illustrate the vitality of e-learning.

When individual course components were examined, students responded favorably to the availability of online lecture notes, discussion section, availability of web links, and inclusion of calendar entries. Online exams were viewed as convenient (72.8\%) and students appreciated that they received an instant grade and feedback after taking exams (89.7\%). Additionally, less than half of the students $(45.6 \%)$ said that they prefer to take quizzes and exams in person with $27.2 \%$ neutrality. The most popular feature noted in this study was the assignment section with $79.8 \%$ agreeing/ strongly agreeing that they enjoyed submitting assignments online, $66.6 \%$ agreeing/strongly agreeing that they prefer the online submission of assignments, and an overwhelming $99.1 \%$ responding that they liked that they had the ability to check assignment grades online. These findings are in agreement with research conducted by Salaway and Caruso (2007) and Wernet, Olliges, and Delicath (2000) who found that course Websites have proved to be an effective means of delivering learning materials, Derouza and Fleming (2003) who reported positive 
findings with respect to students and online assessments, and Salaway and Caruso, (2007) and Barrack (2005) who found that students prefer online assignment submission.

Finally, although students were largely satisfied with their online learning experience the students were mixed as to whether they plan on taking an online course in the future with $52.9 \%$ saying yes and $47.1 \%$ responding no.

The results of this study further enforce the assertion that e-learning as a supplement to face-toface instruction enhances the overall learning experience (I. Allen \& Seaman, 2003; BuzzettoMore \& Sweat-Guy, 2006; Lorenzetti, 2005; Young, 2002) and that online learning has the ability to provide learners with more choices, greater flexibility, expanded resources, and increased opportunities, while offering faculty an opportunity to teach using alternative delivery and assessment methods (Matheos \& Curry, 2004). It has also shown that asynchronous instruction can result in high levels of student satisfaction (Buzzetto-More \& Sweat-Guy, 2006; Sanders \& Morrison-Sheltar, 2002; Yip, 2004). Finally, it suggests that course Website adoption should continue at minority serving institutions.

\section{References}

Allen, I., \& Seaman, J. (2003). Sizing the opportunity: The quality and extent of online education in the United States, 2002-2003. Needham, MA: Sloan.

Anastasiades, P., \& Retalis, S. (2001). The educational process in the emerging information society: Conditions for the reversal of the linear model of education and the development of an open type hybrid leaning environment. Proceedings of ED-MEDIA 2001, Tampere, Finland, June 25-30. 43-50

Allen, W. (1987) Black college vs. white college: The fork in the road for black students. Change, 19, 2834.

Arnone, M. (2002, 5 April). Historically black colleges grapple with online education. The Chronicle of Higher Education, A27. Available online at http://chronicle.com/free/v48/i30/30a02701.htm

Bohr, L. Pascarella, E., Nora, A., \& Terenzini, P. (1995). Do black students learn more at historically black or predominantly white colleges? Journal of College Student Development, 36, 75-85.

Berube, D., Murray, C., \& Schultz, K. (1999). Cadaver and computer use in the teaching of gross anatomy in physical therapy education. Journal of Physical Therapy Education, 13(2), 41-46.

Barack, L. (2005). No more lost homework. School Library Journal, 51(5), 28.

Buzzetto-More, N., \& Sweat-Guy, R. (2006). Incorporating the hybrid learning model into minority education at a historically black university. Journal of Information Technology Education, 5, 153-164. Retrieved from http://www.jite.org/documents/Vol5/v5p153-164Buzzetto130.pdf

Buzzetto-More, N., \& Sweat-Guy, R. (2007). The technology ownership and information acquisition habits of HBCU freshmen. Interdisciplinary Journal of Information, Knowledge, and Management, 2(1), 59-72. Retrieved from http://ijikm.org/Volume2/IJIKMv2p059-072Buzzetto252.pdf

Campos, M., \& Harasim, L. (1999). Virtual-U: Results and challenges of unique field trials. Retrieved May 2005, from the Technology Source Web Site: http://ts.mivu.org/default.asp?show=article\&id=1034

Carnevale, D. (2000). Study assesses what participants look for in high-quality online courses. Chronicle of Higher Education, 47(9), A46.

Carswell, L., Thomas, P., Petre, M., Price, B., \& Richards, M. (2000). Distance education via the internet: the student experience. British Journal of Educational Technology, 31(1, 29-46.

Caruso, J., \& Kvavik, R. (2005). Students and information technology, 2005: Convenience, connection, control and learning. Educause Center for Applied Research. Available at www.educause.edu/ecar) 
Connolly, T., \& Stansfield, M. (2007). Developing constructivist learning environments to enhance elearning. In N. Buzzetto-More, Principles of effective online teaching (pp. 19-38). Santa Rosa: CA, Informing Science Press.

Derouza, E., \& Fleming, M. (2003). A comparison of in-class quizzes vs. online quizzes on student exam performance. Journal of Computing in Higher Education, 14, 121-134.

DeSousa, D. J., \& Kuh, G. D. (1996). Does institutional racial composition make a difference in what Black students gain from college? Journal of College Student Development, 37, 257-267.

DeVillers, R. (2007). The six C's framework for e-learning. In N. Buzzetto-More, Advanced principles of effective e-learning (pp.1-25). Santa Rosa: CA, Informing Science Press.

Dziuban, C., \& Moskal, P. (2001). Evaluating distributed learning at metropolitan universities. Educause Quarterly, 24(4), 60-61.

Flowers, L. (2002). The impact of college racial composition on African American students' academic and social gains: Additional evidence. Journal of College Student Development, 43(3), 403-410.

Flowers, L., \& Pascarella, E. T. (1999). Cognitive effects of college racial composition on African American Students after 3 years of college. Journal of College Student Development, 40(6), 669-677.

Fries-Britt, S., \& Turner, B. (2002). Uneven stories: Successful black collegians at a black and white campus. The Review of Higher Education, 25(3), 315-330.

Hubbard, D. (2006). The color of our classroom, the color of our future. Academe, 92(6), 27-29.

Hurd, H. (2000, November). Majority of HBCU's 'keeping pace' with technology: Historically black colleges and universities, provide internet access. Black Issues in Higher Education. Retrieved August 8 , 2006 from http://www.findarticles.com/p/articles/mi_m0DXK/is_19_17/ai_68503555

Institute of Education Sciences, U.S. Department of Education. (2003). Internet access in U.S. public schools and classrooms: 1994-2002. Retrieved June 29, 2005 from the National Center for Education Statistics Web Site: http://nces.ed.gov/pubs2004/2004022.pdf

Jackson, L., Ervin, K., Gardner, P., \& Schmitt, N. (2001). The racial digital divide: Motivational, affective, and cognitive correlates of Internet use. Journal of Applied Social Psychology, 31(10), 2019-2046.

Koohang, A., \& Harmon, K. (2005). Open source: A metaphor for e-learning. Informing Science Journal, 8, 76-86. Retrieved from http://inform.nu/Articles/Vol8/v8p075-086Kooh.pdf

Laird, T., Bridges, B., Homes, M., Morelon, C., \& Williams, J. (2004). African American and Hispanic student engagement at minority serving and predominantly white institutions. Paper presented at the Annual Meeting of the Association for the Study of Higher Education, November 4-7, 2004, Kansas City, MO.

Lesh, S., Guffey, J., \& Rampp, L. (2000). Changes in student attitudes regarding a web-based health profession course (Reports - Research HE032863). U.S.; Arkansas: Higher Education.

Lewis, B., MacEntee, V., DeLaCruz, S., Englander, C., Jeffrey, T., Takach, E., Wilson, S., \& Woodall, J. (2005). Learning management systems comparison. Proceedings of the 2005 Informing Science and IT Education Joint Conference. Retrieved from http://proceedings.informingscience.org/InSITE2005/P03f55Lewis.pdf

Lorenzetti, J. (2005). Lessons learned about student issues in online learning. Distance Education Report, $9(6), 1-4$.

Kandies, J., \& Stern, M. B. (1999). Weaving the Web into the classroom: An evolution of Web enhanced instruction. Paper presented at the Teacher Education International Conference, San Antonio, TX. (ERIC Document Reproduction Service No. ED 432270).

Matheos, K., \& Curry, J. (2004). Online learning: Changes policies and practices. In Occasional Papers in High Education Number 12, Advances and Challenges in e-learning at Canadian Research Universities, Centre for Higher education Research and Development, University of Manitoba. 
Morgan, J., \& VanLengen, C. (2005) The digital divide and K-12 student computer usage. Issues in Informing Science and Information Technology, 2, 705-724. Retrieved from http://proceedings.informingscience.org/InSITE2005/I56f86Morg.pdf

National Telecommunications and Information Administration. (2000). Falling through the net: Towards digital inclusion. National Telecommunications and Information Administration. U.S. Department of Commerce. Washington D.C.

Nycz, M. \& Cohen, E. (2007). The basics for understanding e-learning. In N. Buzzetto-More, Principles of effective online teaching (pp. 1-17). Santa Rosa: CA, Informing Science Press.

Outcalt, C., \& Skewes-Cox, T. (2002). Involvement, interaction, and satisfaction: The human environment at HBCUs. The Review of Higher Education, 25(5), 331-347.

Rivera, J., McAlister, K., \& Rice, M. (2002). A comparison of student outcomes \& satisfaction between traditional \& web based course offerings. Online Journal of Distance Learning Administration, 5(3), 151-179.

Salaway, G., Katz, R., \& Caruso, J., (2006). The study of undergraduate students and information technology. EDUCAUSE Center for Applied Research, Volume 7. Retrieved January 22, 2008 from www.educause.edu/ecar/

Salaway, G., \& Caruso, J. B. (2007, September 12). The ECAR study of undergraduate students and information technology 2007. Retrieved March 22, 2007, from Educause Connect: http://connect.educause.edu/library/abstract/TheECARStudyofUnderg/45075

Sanders, D., \& Morrison-Shetlar, A. (2002). Student attitudes toward web-enhanced instruction in an introductory biology course. Journal of Research on Computing in Education, 33(3), 251-262.

Sax, L., Ceja, M., \& Teranishi, R. (2001). Technological preparedness among entering freshmen: The role of race, class, and gender. Journal of Educational Computing Research, 24(4), 363-383.

Seifert, T. A., Drummond, J., \& Pascarella, E. T. (2006). African-American students' experiences of good practices: A comparison of institutional type. Journal of College Student Development, 47(2), 185-205.

Ukoha, O., \& Buzzetto-More, N. (2007). Bridging the gap through pre-college readiness programs: The impact of a summer bridge program on the mathematical abilities of under-prepared college freshmen at a minority serving institution. Manuscript submitted for publication.

United States Department of Commerce. (2002). A nation online: How Americans are expanding their use of the Internet. U.S. Department of Commerce, Economics and Statistics Administration, National Telecommunications and Information Administration. Washington, D.C.

Watson, L. W., \& Kuh, G. D. (1996). The influence of dominant race environments on student involvement, perceptions, and educational gains: A look at historically Black and predominantly White liberal arts institutions. Journal of College Student Development, 37, 415-424.

Wernet, S., Olliges, R., \& Delicath, T. (2000). Postcourse evaluations of WebCT (Web Course Tools) classes by social work students. Research on Social Work Practice, 10(4), 487-504.

Wu, D. \& Hiltz, R. (2004). Predicting learning from asynchronous online discussions. Journal of Asynchronous Learning Networks, 8(2), 139-152.

Yip, M. C. W. (2004). Using WebCT to teach courses online. British Journal of Educational Technology, 35(4), 497-501.

Young, J. (2002). "Hybrid" teaching seeks to end the divide between traditional and online instruction. Chronicle of Higher Education, 48(28), A33. 


\section{Biography}

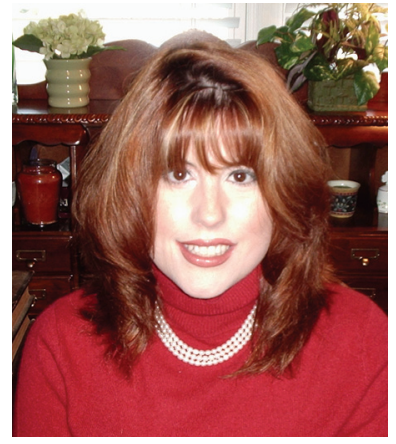

Dr. Nicole A. Buzzetto-More is an Associate Professor, Business Education program coordinator, and Assurance of Learning coordinator in the Department of Business, Management, and Accounting at the University of Maryland Eastern Shore. She is also Co-Founder of the UMES Office of Instructional Technology. She received doctorate and masters degrees in communication and instructional technology from Columbia University and also holds degrees from the College of New Rochelle and Marist College. As a recognized assessment and elearning expert, she is a frequent presenter at conferences across the globe. She is on the editorial and review boards of several journals, has authored numerous publications in referred journals, and has been recognized with awards from the American Distance Education Consortium, Global Digital Business Association, and the Informing Science Institute. Her two books published in early 2007, Principles of Effective Online Teaching and Advanced Principles of Effective E-Learning, are available through the Informing Science Press. 